\title{
The Effect of Light-dependent Application of Nitrate on the Growth of Aeroponically Grown Lettuce (Lactuca sativa L.)
}

\author{
Jernej Demšar, Jože Osvald, and Dominik Vodnik ${ }^{1}$ \\ University of Ljubljana, Biotechnical Faculty, Agronomy Department, Jamnikarjeva 101, SI-1001 \\ Ljubljana, Slovenia
}

\begin{abstract}
ADDITIONAL INDEX WORDS. nitrate accumulation, nitrogen, mineral nutrition, yield, photosynthesis, computerized aeroponic system

Abstract. With a high nitrate supply, and most frequently under low-light conditions, lettuce accumulates relatively large amounts of $\mathrm{NO}_{3}$ - as a result of an excess of uptake over reduction. Different approaches, which are used to reduce leaf nitrate, often result in a yield loss. A computerized aeroponic system, which supplies different nitrate concentrations in accordance with the changeable light conditions (dynamic light-dependent application of nitrate), was used to reduce nitrate accumulation in lettuce (Lactuca sativa L.) var. Capitata cv. Vanity. Under unfavorable light conditions nitrate was supplied at limited rates (slight, medium, and strong reduction) to the plants. In response to given light conditions the nitrate supply was reduced close to one-half or one-fourth of the full nutrient $\operatorname{solution}\left(8 \mathrm{mmol} \cdot \mathrm{L}^{-1}\right.$ $\mathrm{NO}_{3}-$ ). Controlled nutrition resulted in efficient reduction in leaf nitrate. In the early-spring experiment the average nitrate content in outer leaves was decreased by $9 \%, 63 \%$, and $92 \%$ and in the late-spring experiment the decrease was $23 \%, 58 \%$, and $76 \%$ compared to control. At the same time, the controlled, light-dependent nitrate deprivation did not result in a loss of a lettuce yield (except in the treatment with strong nitrate reduction) and had limited effects on photosynthesis $\left(P_{\mathrm{N}}-C_{\mathrm{i}}\right.$ measurements) and photosynthetic pigments.
\end{abstract}

Several plant species accumulate $\mathrm{NO}_{3}$ - as a result of an excess of uptake over reduction. The accumulation is most frequently present under low-light conditions (Blom-Zandstra and Lampe, 1985; Cantliffe, 1972; Steingröver et al., 1986). Nitrate content is increased as a result of the shortage of reducing equivalents and carbon skeletons, due to down-regulated nitrate reductase (Appenroth et al., 2000) and feedback regulation by amino acids accumulated as a result of low demand for growth (Marschner, 1995; Tischner, 2000). The accumulation is especially evident in plants that use nitrate in vacuoles for osmoregulation (BlomZandstra et al., 1988). In these, with reduced light intensity, nitrate replaces sugars in their osmotic function (Blom-Zandstra and Lampe, 1985; Steingröver et al., 1986).

Since nitrate has been implicated in the occurrence of methemoglobinemia and possibly in gastric cancer its content in edible plant tissues is an important criterion of vegetable quality. Acceptable leaf nitrate concentrations in vegetables are set by legislation. For lettuce, the limit set by the European Union is 4500, 3500, and $2500 \mathrm{mg} \cdot \mathrm{kg}^{-1} \mathrm{NO}_{3}$ - fresh weight (FW), for winter-, summer-, and open-grown lettuce, respectively (Official Journal, 1998).

Nitrate accumulation in plants can be influenced by supplying correct plant nutrition, controlling environmental conditions, and using appropriate genetic material. Many research workers have tried to reduce the nitrate content by 1 ) reducing the concentration of N in the nutrient solution (Andersen and Nilsen, 1992; Maršić and Osvald, 2002a, 2002b; Van Der Boon et al., 1990), 2) changing N forms in different ratios (Günes et al., 1994; Kowalska, 1997; Santamaria et al., 1997a, 1997b; Scaife et al., 1986; Van Der Boon et al., 1990), 3) reducing the concentration or interrupting $\mathrm{N}$ supply a few days prior to the harvest (Malorgio et al., 1995; Schonbeck et al., 1991), 4) supplying Cl- as an antagonist to

Received for publication 10 Mar. 2003. Accepted for publication 21 Jan. 2004. 'Corresponding author; e-mail address: dominik.vodnik@bf.uni-lj.si nitrate ions absorption (Günes et al., 1994; Malorgio et al., 1995; Urrestarazu et al., 1998), 5) modifying microclimatic factors (Alt and Full, 1988; Blom-Zandstra and Lampe, 1985; Gaudreau et al., 1995), and 6) screening different plant varieties for nitrate accumulation (Behr and Wiebe, 1992; Blom-Zandstra et al., 1988; Blom-Zandstra and Eenink, 1986; Escobar-Gutierrez et al., 2002). By using different approaches, a $20 \%$ to $40 \%$ reduction of leaf nitrate content can be achieved. Unfortunately variable experimental conditions and setups limit an efficient comparison of the listed methods.

In lettuce, the nitrate content can be very efficiently reduced by limited nitrate supply. Such reduction often results in a yield loss, especially when nitrate deprivation is not accompanied by regulation of other factors influencing lettuce growth and $\mathrm{N}$ assimilation (Andersen and Nilsen, 1992; Henriques and Marcelis, 2000; Maršić and Osvald, 2002a, 2002b; Van Der Boon et al., 1990). Decrease of lettuce yield can be dependent on the season (Van Der Boon et al., 1990) and light-dependent effects are known from the study by Henriques and Marcelis (2000) where dry matter production in lettuce was significantly decreased when $\mathrm{N}$-deprived plants were grown at high irradiance but decreased only slightly at low irradiance.

The availability of modern technologies and crop models makes it possible to develop an optimal control strategy for greenhouse-grown lettuce and some of the approaches can also help to maintain an acceptable level of nitrate content (Ioslovich and Seginer, 2002). To our knowledge, however, there have been no attempts to use a light-dependent nutrient application in order to reduce the nitrate content with concomitant optimization of growth. In our study a computerized aeroponic system, which supplies different nitrate concentrations in accordance with the changeable light conditions (slight, medium, and strong reduction of nitrate supply under limiting daylight), was used to reduce nitrate accumulation in lettuce. The objectives were to achieve nitrate reduction by dynamic light-dependent application of 
nitrate without concomitant yield loss known from our previous study when lettuce was continuously limited in nitrate (Maršić and Osvald, 2002a, 2002b). In addition, the aim of the study was to compare the effects of different nitrate deprivation regimes by measurements of growth and photosynthetic parameters.

\section{Materials and Methods}

Experimental DESign. Two experiments with lettuce cultivar Vanity (Enza Zaden, the Netherlands) were carried out in a greenhouse system (polyethylene plastic film, $0.18 \mathrm{~mm}$ ) on a laboratory field at the Biotechnical Faculty in Ljubljana (lat. $46^{\circ} 04^{\prime} \mathrm{N}$, long. $14^{\circ} 31^{\prime} \mathrm{W}$, above $300 \mathrm{~m}$ M.S.L.), from 20 Mar. 2002 to $30 \mathrm{Apr}$. 2002 and from 20 May 2002 to 19 June 2002. The plants were grown in the aeroponic system under natural daylight condition, without additional illumination.

Lettuce was sown into a seedling tray and repotted into plastic net-pots filled with rockwool (diameter of $5.5 \mathrm{~cm}$ ) $25 \mathrm{~d}$ after sowing. At the same time, seedlings were fertiirigated with modified Resh's nutrient solution (Resh, 1995) $\left(\mathrm{mmol} \cdot \mathrm{L}^{-1}\right): 5 \mathrm{Ca}\left(\mathrm{NO}_{3}\right)_{2}$, $1.6 \mathrm{KH}_{2} \mathrm{PO} 4,1.9 \mathrm{~K}_{2} \mathrm{SO} 4,1.8 \mathrm{NH}_{4} \mathrm{NO}_{3}, 1.6 \mathrm{MgSO}_{4} \cdot 7 \mathrm{H}_{2} \mathrm{O}, 9.0 \times$ $10^{-2} \mathrm{Fe}-$ Sequestrene, $1.6 \times 10^{-3} \mathrm{CuSO}_{4} \times 5 \mathrm{H}_{2} \mathrm{O}, 0.5 \times 10^{-3} \mathrm{MoO}_{3}$, $9.1 \times 10^{-3} \mathrm{MnSO}_{4}, 1.5 \times 10^{-4} \mathrm{ZnSO}_{4} \times 7 \mathrm{H}_{2} \mathrm{O}, 1.4 \times 10^{-2} \mathrm{H}_{3} \mathrm{BO}_{4}$. When rockwool was overgrown by the roots ( $10 \mathrm{~d}$ after repotting) the plants were transferred to the aeroponic system.

A computerized aeroponic system was constructed by using an aeroponic chamber with the tube system and micro-sprayers, PC-computer, quantum sensor (LI-190SA), six tanks for nutrient solutions, and pumps. Nutrient solution was sprayed in the aeroponic chamber for $1 \mathrm{~min}$ in 5-min intervals. Every minute photon flux density ( $P F D)$ was measured and then an hour average value of $P F D$ calculated. This was the basis for a modulation of nitrate supply for the next hour (Table 1).

Resh's nutrient solution with $8 \mathrm{mmol} \cdot \mathrm{L}^{-1} \mathrm{NO}_{3}$ - (Resh, 1995) was used as the base for nutrition. Modified nutrient solutions with the same composition but different amounts of $\mathrm{NO}_{3}-(8,6,4,2$, $\left.1,0.5 \mathrm{mmol} \cdot \mathrm{L}^{-1}\right)\left[\mathrm{Ca}\right.$ originating from $\mathrm{Ca}\left(\mathrm{NO}_{3}\right)_{2}$ in full-strength solution was replaced by water-soluble $\mathrm{CaO}$ ] were applied according to four light regimes, i.e., PFD intervals (Table 1), which were selected on the basis of photosynthetic light response curves $\left(P_{\mathrm{N}^{-}}-P F D\right)$. These measurements showed that photosynthetic light

Table 1. Four treatments with combination of photon flux density interval and $\mathrm{N}$ concentration in nutrient solution.

\begin{tabular}{|c|c|c|c|}
\hline \multicolumn{2}{|c|}{ Treatment } & $\begin{array}{l}\text { Photon flux density } \\
\left(\mu \mathrm{mol} \cdot \mathrm{m}^{-2} \cdot \mathrm{s}^{-1}\right)\end{array}$ & $\begin{array}{c}\text { Concn of } \\
\mathrm{NO}_{3^{-}}\left(\mathrm{mmol} \cdot \mathrm{L}^{-1}\right)\end{array}$ \\
\hline \multirow[t]{4}{*}{$\overline{\mathrm{A}}$} & \multirow{4}{*}{$\begin{array}{l}\text { Constant } \mathrm{NO}_{3^{-}} \\
\text {supply }\end{array}$} & $>600$ & 8 \\
\hline & & $300-600$ & 8 \\
\hline & & $20-300$ & 8 \\
\hline & & $<20$ & 8 \\
\hline \multirow[t]{4}{*}{ B } & \multirow{4}{*}{$\begin{array}{l}\text { Slightly reduced } \\
\mathrm{NO}_{3} \text { - supply }\end{array}$} & $>600$ & 8 \\
\hline & & $300-600$ & 6 \\
\hline & & $20-300$ & 4 \\
\hline & & $<20$ & 2 \\
\hline \multirow[t]{4}{*}{$\mathrm{C}$} & \multirow{4}{*}{$\begin{array}{l}\text { Medium reduced } \\
\mathrm{NO}_{3} \text { - supply }\end{array}$} & $>600$ & 8 \\
\hline & & $300-600$ & 4 \\
\hline & & $20-300$ & 2 \\
\hline & & $<20$ & 1 \\
\hline \multirow[t]{4}{*}{$\mathrm{D}$} & Strongly reduced & $>600$ & 8 \\
\hline & $\mathrm{NO}_{3}$ - supply & $300-600$ & 4 \\
\hline & & $20-300$ & 1 \\
\hline & & $<20$ & 0.5 \\
\hline
\end{tabular}

saturation is reached at $500-600 \mu \mathrm{mol} \cdot \mathrm{m}^{-2} \cdot \mathrm{s}^{-1}$ (data not shown). In treatments B, C, and D, nitrate-limited modified nutrient solutions were used during the period of low photon flux. When nutrient solutions with different nitrate contents were successively applied in response to changing light intensity the aeroponic chamber and the lettuce root system were rinsed with tap water for $1 \mathrm{~min}$.

Thirty-two plants were subjected to a single treatment (nutrition regime) and altogether there were 128 plants in one experiment.

Measurements. During the trial, nutrient solution conductivity was kept between 1 and $1.9 \mathrm{mS} \cdot \mathrm{cm}^{-1}$ and $\mathrm{pH}$ was balanced at 5.5 to 6.5 by the addition of $30 \%$ sulphurous acid. During both experiments air temperature and humidity and temperature of the aeroponic chamber were measured.

Photosynthesis $\left(P_{\mathrm{N}}\right)$ of lettuce leaves was measured with the LI-6400 portable photosynthesis system(LI-COR, Lincoln, Nebr.). Light response curves were recorded at photon flux densities of $1200,1000,800,600,500,400,300,200,100$, and $0 \mu \mathrm{mol} \cdot \mathrm{m}^{-2} \cdot \mathrm{s}^{-1}$ and at $360 \mu \mathrm{mol} \cdot \mathrm{mol}^{-1} \mathrm{CO}_{2}$ once just before the start of the first experiment, to set photon flux intervals for light-dependent application of nutrients, and in the second week of both experiments. In the last week of experiments photosynthetic dependency on intercellular $\mathrm{CO}_{2}$ concentration $\left(P_{\mathrm{N}^{-}} C_{\mathrm{i}}\right.$ curves; $\mathrm{CO}_{2}$ ref $=1200$, $\left.800,400,300,200,100,50,0 \mu \mathrm{mol} \cdot \mathrm{mol}^{-1} \mathrm{CO}_{2}\right)$ was measured at $P F D$ of $800 \mu \mathrm{mol} \cdot \mathrm{m}^{-2} \cdot \mathrm{s}^{-1}$.

The chlorophyll content was measured on lettuce leaves by using a portable chlorophyll PFD meter (Minolta SPAD), once in the middle of the experiment and once at the harvest. Three replicate measurements were done on the single leaf and three leaves (outer, middle, and inner) were measured per plant. All plants from the treatment were subjected to a chlorophyll analysis.

At the end of experiments lettuce shoot and root weight and the height and width of heads were measured. Dry matter of the root and leaf samples was evaluated after they were oven-dried for $3 \mathrm{~d}$ at $55^{\circ} \mathrm{C}$.

The content of nitrate in outer and inner leaves was measured photometrically (AutoAnalyzer II, SFA, New York) according to standardized procedure (ISO/DIS 14255, L. 1995). Total N was measured by using macro-Kjeldahl method (ISO/FDIS 5983, L. 1979).

Statistical MEthods. The nonlinear regression models (Vodnik et al., 2002) were fitted to the net $\mathrm{CO}_{2}$-exchange $\left(P_{\mathrm{N}}\right)$ as response variable, and $P F D$ or intercellular $\mathrm{CO}_{2}$ concentrations $\left(C_{\mathrm{i}}\right)$ as explanatory variable. From $P_{\mathrm{N}}-C_{\mathrm{i}}$ curves, $\mathrm{CO}_{2}$-saturated photosynthesis $\left(\mu \mathrm{mol} \cdot \mathrm{m}^{-2} \cdot \mathrm{s}^{-1}\right)$, carboxylation efficiency $\left(\mathrm{mol} \cdot \mathrm{m}^{-2} \cdot \mathrm{s}^{-1}\right)$, and $\mathrm{CO}_{2}$ compensation point $\left(\mu \mathrm{mol} \cdot \mathrm{mol}^{-1}\right)$ were derived and compared by $t$ test between the treatments.

The results on growth parameters and the content of nitrate and total $\mathrm{N}$ were analyzed by one-way analysis of variance (ANOVA) followed by Tukey's HSD test.

The statistical analysis was performed by Statgraphics Plus (Manugistic, Rockville, Md.) software.

\section{Results}

The greenhouse temperature varied between 6 and $31^{\circ} \mathrm{C}$ in the first experiment and 10 and $34{ }^{\circ} \mathrm{C}$ in the second experiment. In both experiments, the average air humidity was $\approx 70 \%$ and daily values of sun radiation in the greenhouse on a sunny day were between 5 and $6 \mathrm{kWh} \cdot \mathrm{m}^{-2}$.

Continuous measurements of $P F D$ enable us to estimate the length of the periods with the specific light conditions (selected 
PFD intervals) (Fig. 1). In the first experiment, carried out in the early spring, $P F D$ was $\leq 20 \mu \mathrm{mol} \cdot \mathrm{m}^{-2} \cdot \mathrm{s}^{-1}$ more than half time $(52 \%)$ of the experimental run-time. $P F D$ exceeded $600 \mu \mathrm{mol} \cdot \mathrm{m}^{-2} \cdot \mathrm{s}^{-1}$ only for $99 \mathrm{~h}, 10 \%$ of the time. These results can be due to the long nights, frequent morning fog, and changeable weather in March and April. In the second experiment, carried out in the late spring, the period of light conditions corresponding to the lowest $P F D$ interval $\left(<20 \mu \mathrm{mol} \cdot \mathrm{m}^{-2} \cdot \mathrm{s}^{-1}\right)$ was shorter $(44 \%$ of the experimental run-time). In $19 \%$ of the time $P F D$ exceeded 600 $\mu \mathrm{mol} \cdot \mathrm{m}^{-2} \cdot \mathrm{s}^{-1}$

Taking into account the length of periods with different light intensity, average concentration of supplied nitrate was calculated for all four treatments (Table 2). In response to light conditions the nitrate supply in treatment B was reduced to $45.0 \%$ and $51.3 \%$ of the full supply $\left(8 \mathrm{mmol} \cdot \mathrm{L}^{-1}\right.$, treatment $\left.\mathrm{A}\right)$ for the first and second experiment, respectively. More strict nitrate deprivation regime in treatments $\mathrm{C}$ and $\mathrm{D}$ (see Table 1 ) resulted in $\approx 70 \%$ to $80 \%$ reduction of nitrate supply (Table 2). Higher average concentration of $\mathrm{NO}_{3}$ - in the second experiment $(\mathrm{B}, \mathrm{C}$, and $\mathrm{D}$ treatments) can be due to better light conditions in the late spring.

The effect of light-dependent application of nitrate on the shoot and root fresh and dry weight and the shoot : root ratio is presented in Table 3. The growth analysis revealed that slight and medium reduction of nitrate supply (treatments B and C) did not decrease yield parameters, irrespective of the season. In both experiments however, a decrease in leaf fresh weight was observed in response to strong deprivation of nitrate (treatment D). In the same treatment the heads did not reach technological maturity and were less compact at harvest. The average height of lettuce heads was reduced with nitrate deprivation $(\mathrm{A}=29, \mathrm{~B}=$ $28.5, C=26.5$, and $D=21.5 \mathrm{~cm}$ in the first experiment; $A=30$, $\mathrm{B}=27.5, \mathrm{C}=25.5, \mathrm{D}=24 \mathrm{~cm}$ in the second experiment). The effect of nitrate limitation was less pronounced with the heads width, which was significantly decreased only with the strong limitation of $\mathrm{NO}_{3}$ - in the first experiment (data not shown).

There were also noticeable differences in the root growth. Plants in the control treatment (A) had longer main roots in comparison to other treatments (data not presented), but root fresh mass was statistically higher in the treatments with medium and strongly reduced $\mathrm{NO}_{3}-(\mathrm{C}$ and $\mathrm{D})$ (Table 3 ). With increased root and decreased shoot fresh weight in response to $\mathrm{NO}_{3}$ - deprivation, lower shoot : root ratios can be observed in treatments $\mathrm{C}$ and $\mathrm{D}$.

The leaf dry matter content was similar in all treatments, whereas a significantly higher root dry matter content was measured in plants roots with limited $\mathrm{NO}_{3}$ - supply (treatments $\mathrm{B}, \mathrm{C}$, and D) when compared to full and constant nitrate supply (Table 3).

The nitrate content in lettuce inner and outer leaves was strongly dependent on the concentration of $\mathrm{NO}_{3}$ - in the nutrient solution. Significant differences in the nitrate content between treatments were found (Fig. 2). In the first experiment, the average nitrate contents in outer leaves were $9 \%, 63 \%$, and $92 \%$ lower in B, C, D treatments, respectively, when compared to plants permanently supplied with the full nutrient solution (treatment $\left.\mathrm{A}=2440 \mathrm{mg} \cdot \mathrm{kg}^{-1} \mathrm{NO}_{3}-\mathrm{FW}\right)$. In the second experiment, a 23\%, $58 \%$, and $76 \%$ reduction of leaf $\mathrm{NO}_{3}-$ was found with regard to treatment $\mathrm{A}\left(3320 \mathrm{mg} \cdot \mathrm{kg}^{-1} \mathrm{NO}_{3}-\mathrm{FW}\right)$. In comparison to inner leaves the concentration of nitrate in outer leaves was much higher, 0.5 - to 2-fold in the first and 3- to 5-fold in the second experiment (Fig. 2).

The effect of nitrate deprivation was less pronounced when total $\mathrm{N}$ leaf was concerned. In the first experiment, there was no

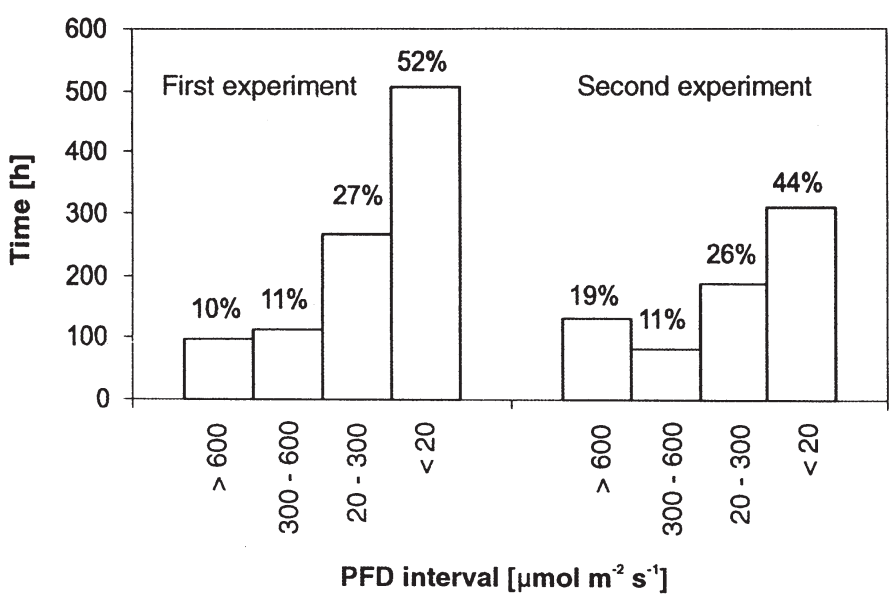

Fig. 1. The length of the periods with the specific light conditions (selected $P F D$ intervals) in two experiments with aeroponically grown lettuce. Sums of the hours with specific average $P F D$ are presented and corresponding percent of the experimental run time are given.

Table 2. Cumulative nitrate supply in different nutritional treatments. Average nitrate concentrations were calculated on the basis of the length of the periods with specific light regimes (Fig. 1 and Table 1), nitrate deprivation is presented as percentage reduction compared to full constant supply.

\begin{tabular}{cccc}
\hline Experiment & Treatment & $\begin{array}{c}\text { Avg concn } \\
\text { of NO} 3^{-} \\
{\left[\mathrm{mmol}^{-1} \mathrm{~L}^{-1}\right]}\end{array}$ & $\begin{array}{c}\text { Reduction of nitrate } \\
\text { compared to } \\
\text { treatment A [\%] }\end{array}$ \\
\hline 1 & A & 8.00 & 100.0 \\
& B & 3.60 & 45.0 \\
& C & 2.32 & 29.0 \\
& D & 1.79 & 22.4 \\
& A & 8.00 & 100.0 \\
B & 4.10 & 51.3 \\
& C & 2.91 & 36.4 \\
D & 2.43 & 30.4 \\
\hline
\end{tabular}

significant difference in the content of total $\mathrm{N}$ in the inner leaves when treatments were compared, but a clear decrease could be observed in outer leaves (Fig. 2). In the second experiment, leaf $\mathrm{N}$ was lower in the outer leaves of lettuce with medium and strongly reduced $\mathrm{NO}_{3}$ - supply (treatments $\mathrm{C}$ and $\mathrm{D}$ ) when compared to constant and slightly reduced $\mathrm{NO}_{3}$ - supply (treatments $\mathrm{A}$ and B). The effect of nitrate deprivation was less distinctive for $\mathrm{N}$ content of inner leaves. When compared to the control, a significant decrease of leaf $\mathrm{N}$ was found in medium reduced nitrate supply only.

Different nitrate supplies did not result in changed photosynthetic activity of middle leaves when measured at saturating light intensity and at different $\mathrm{CO}_{2}$ concentrations (Fig. 3). The most interesting parameter of $P_{\mathrm{N}}-C_{\mathrm{i}}$ curve is its initial slope, which reflects carboxylation efficiency, a measure of Rubisco activity and efficiency. Despite a slightly lower leaf nitrate content, no differences were found among the treatments. In the first experiment $\mathrm{N}$ deprivation did not influence the leaf chlorophyll content. One week before the harvest the average chlorophyll values for outer leaves were $485,484,479$ and $475 \mathrm{mg} \cdot \mathrm{m}^{-2}$ for treatments A, B, $\mathrm{C}$, and $\mathrm{D}$, respectively. The concentration was lower in medium leaves $\left(A=439, B=413, C=412\right.$, and $\left.D=421 \mathrm{mg} \cdot \mathrm{m}^{-2}\right)$ and the lowest in inner leaves $(\mathrm{A}=347, \mathrm{~B}=345, \mathrm{C}=351$, and $\mathrm{D}=$ 
Table 3. Growth parameters of lettuce supplied with different nitrate concentrations according to the changeable light conditions (treatments A-D (Treat.), for the description see Table 1.). Data are shown for first and second experiment (Expt.), means \pm SE are presented, $N=4$. ANOVA, Tukey's HSD test, values followed by different letters are significantly different at $P<0.05$.

\begin{tabular}{lcccccc}
\hline Expt. & Treat. & $\begin{array}{c}\text { Shoot mass } \\
(\mathrm{g})\end{array}$ & $\begin{array}{c}\text { Leaf dry matter } \\
(\%)\end{array}$ & $\begin{array}{c}\text { Root mass } \\
(\mathrm{g})\end{array}$ & $\begin{array}{c}\text { Root dry matter } \\
(\%)\end{array}$ & Shoot : root ratio \\
\hline I & A & $476 \pm 11.18 \mathrm{a}$ & $3.80 \pm 0.24 \mathrm{a}$ & $35.87 \pm 0.69 \mathrm{a}$ & $4.36 \pm 0.08 \mathrm{a}$ & $13.27 \pm 0.20 \mathrm{a}$ \\
& $\mathrm{B}$ & $474 \pm 14.34 \mathrm{a}$ & $3.52 \pm 0.07 \mathrm{a}$ & $36.00 \pm 1.33 \mathrm{a}$ & $5.10 \pm 0.18 \mathrm{~b}$ & $13.21 \pm 0.30 \mathrm{a}$ \\
& $\mathrm{C}$ & $435 \pm 14.58 \mathrm{a}$ & $3.90 \pm 0.17 \mathrm{a}$ & $47.37 \pm 1.74 \mathrm{~b}$ & $4.89 \pm 0.03 \mathrm{~b}$ & $9.31 \pm 0.36 \mathrm{~b}$ \\
& D & $356 \pm 12.41 \mathrm{~b}$ & $3.87 \pm 0.08 \mathrm{a}$ & $50.50 \pm 1.22 \mathrm{~b}$ & $4.89 \pm 0.10 \mathrm{~b}$ & $7.05 \pm 0.18 \mathrm{c}$ \\
II & A & $686 \pm 23.16 \mathrm{a}$ & $4.37 \pm 0.18 \mathrm{a}$ & $56.00 \pm 2.83 \mathrm{a}$ & $3.79 \pm 0.09 \mathrm{a}$ & $12.67 \pm 0.68 \mathrm{a}$ \\
& $\mathrm{B}$ & $662 \pm 16.86 \mathrm{a}$ & $4.40 \pm 0.22 \mathrm{a}$ & $56.00 \pm 2.83 \mathrm{a}$ & $5.07 \pm 0.10 \mathrm{~b}$ & $12.19 \pm 0.57 \mathrm{a}$ \\
& $\mathrm{C}$ & $622 \pm 13.04 \mathrm{a}$ & $4.37 \pm 0.12 \mathrm{a}$ & $78.12 \pm 2.36 \mathrm{~b}$ & $4.77 \pm 0.04 \mathrm{~b}$ & $8.03 \pm 0.22 \mathrm{~b}$ \\
& $\mathrm{D}$ & $503 \pm 15.97 \mathrm{~b}$ & $4.34 \pm 0.05 \mathrm{a}$ & $87.75 \pm 3.64 \mathrm{~b}$ & $5.44 \pm 0.38 \mathrm{~b}$ & $5.82 \pm 0.20 \mathrm{c}$ \\
\hline
\end{tabular}
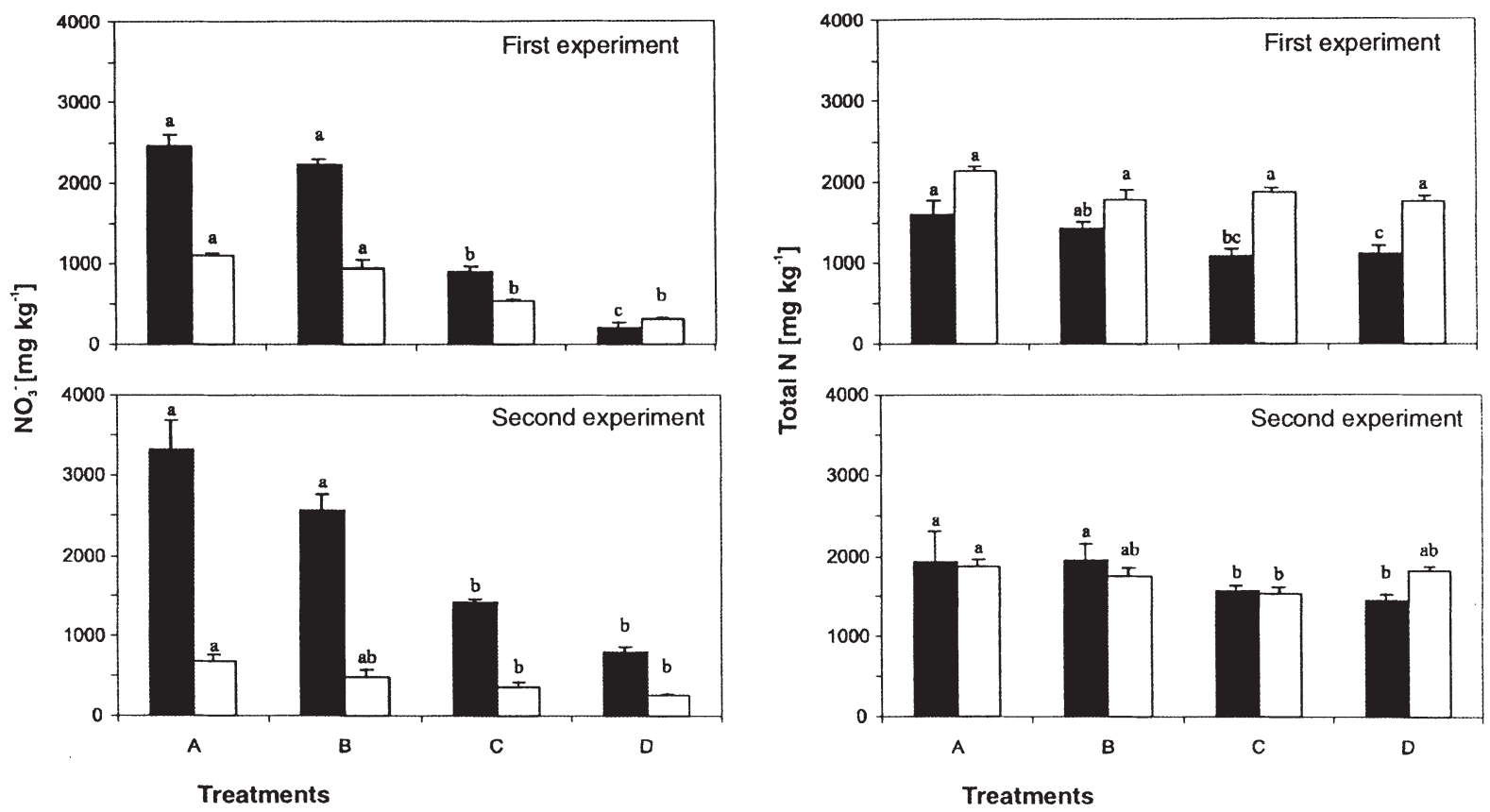

Fig. 2. Average values of nitrate and total $\mathrm{N}$ in the outer $(\square)$ and the inner $(\square)$ leaves of lettuce (Lactuca sativa $\mathrm{L}$.) at different $\mathrm{N}_{\text {treatments. }} \mathrm{A}=$ constant $\mathrm{NO}_{3}$ - supply, $\mathrm{B}$ = slightly reduced $\mathrm{NO}_{3}$ - supply, $\mathrm{C}$ = medium reduced $\mathrm{NO}_{3}$ - supply, $\mathrm{D}=$ strongly reduced $\mathrm{NO}_{3}$ - supply under limiting light conditions (for detailed explanation of the treatments see Table 1). Results are presented for two experiments. Means \pm SE are shown, for the leaves of the same position means indicated by the same letter are not significantly different at $P<0.05$, one-way ANOVA, Tukey's HSD test, $\mathrm{N}=3$.

$353 \mathrm{mg} \cdot \mathrm{m}^{-2}$ ) but was never influenced by nitrate deprivation as revealed by ANOVA.

Similar results were obtained at the end of the second experiment. The only effect of nitrate deprivation on photosynthetic pigments was observed in the middle of the experiment when the chlorophyll content in outer leaves of lettuce strongly limited on nitrate supply was decreased in comparison to the control $(\mathrm{A}=$ $508, \mathrm{D}=460 \mathrm{mg} \cdot \mathrm{m}^{-2}$ ) but at the time of harvest there were again no differences between treatments.

\section{Discussion}

Daylight is an important factor affecting plant growth and development and is one of the key determinants of technologies in vegetable production. In the optimization of plant production it has been shown that yield quality and quantity can be improved by a light-dependent application of mineral nutrients. It is, however, not easy to control nutrient solution application in accordance with changeable light conditions. In the study on cucumber, the rate of nutrient supply during the day was set on the basis of morning PFD measurements (Roh and Lee, 1996). With unsettled weather conditions, however, accuracy of predicted light intensity and possibility of precise nutrition decreased. In our research, a computerized aeroponic system with continuous (every minute) PFD measurements was used. Although there was a 1-h shift in modulation of nutrition, i.e., nitrate supply was modulated in the next hour, in response to previous hour's average $P F D$, we think that the regulation of the system was precise enough to achieve a dynamic supply of nutrients.

In response to changeable light conditions nitrate supply was limited to the levels close to one-half or one-fourth of the full ( 8 $\mathrm{mmol} \cdot \mathrm{L}^{-1}$ ) nutrient solution, when average cumulative concentrations are calculated for treatments B, C, and D (Table 2). Similar reduced concentrations have been used in systems with constant $\mathrm{NO}_{3}$ - supply. In the experiment by Maršić and Osvald (2002a, 2002 b) performed under similar climatic conditions (i.e., location), 


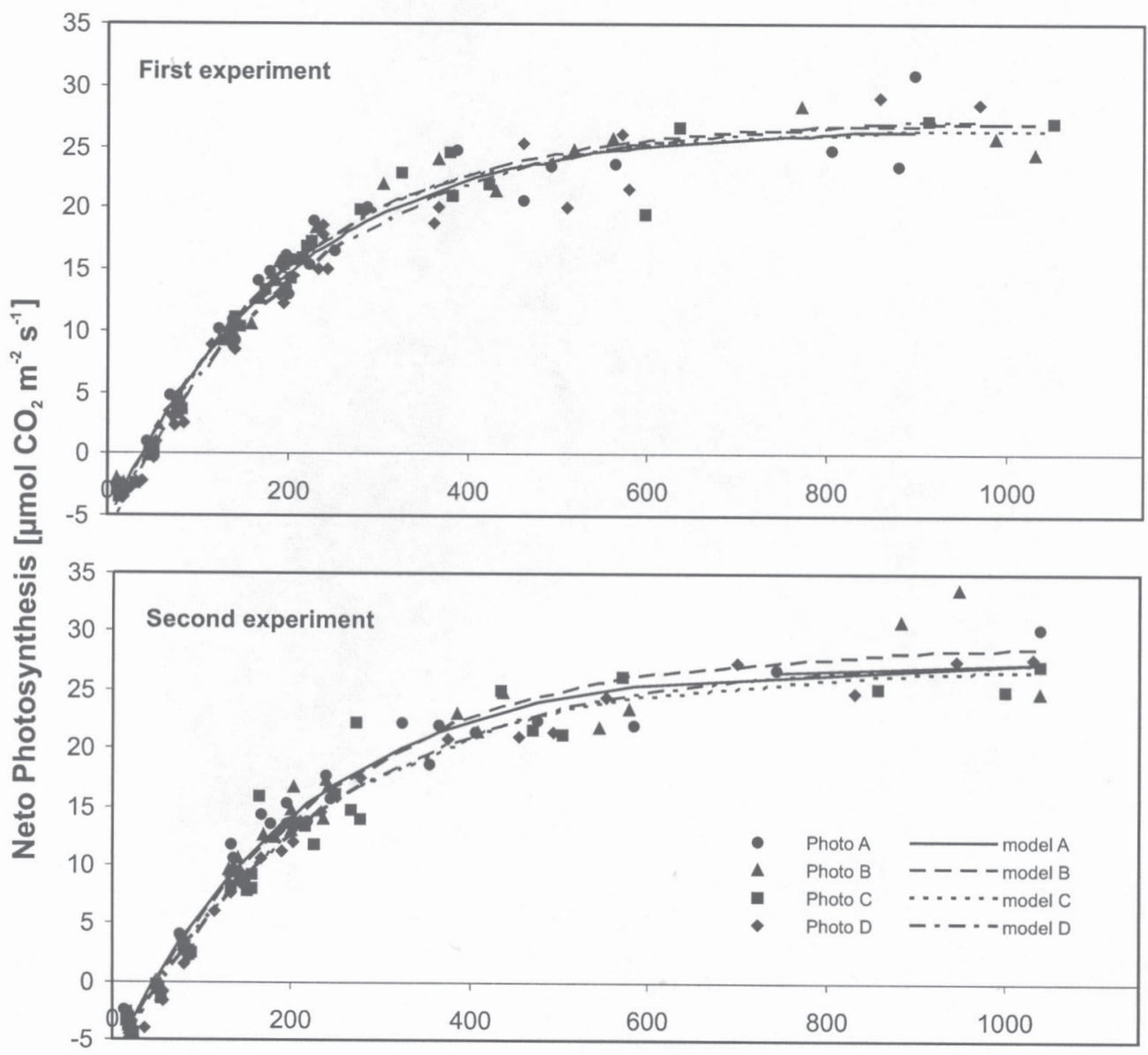

Ci $\left[\mu \mathrm{mol} \mathrm{mol}{ }^{-1}\right]$

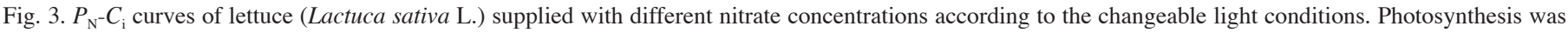
measured in middle leaves on four plants per treatment. Models were calculated using equation $P_{\mathrm{N}}=\beta_{0}\left[1-\exp \left(-\beta_{1}(C \mathrm{i}-\Gamma)\right]\right.$.

the same lettuce cultivar Vanity was aeroponically grown using a nutrient solution with 12,8 , and $4 \mathrm{mmol} \cdot \mathrm{L}^{-1} \mathrm{NO}_{3^{-}}$. A substantial decrease in leaf nitrate was found $\left(2550,2360\right.$, and $1080 \mathrm{mg} \cdot \mathrm{kg}^{-1}$ FW, respectively), but it was accompanied with a significant decrease in shoot fresh weight $(375,372$, and $250 \mathrm{~g})$. When nitrate supply was constantly reduced from 8 to $4 \mathrm{mmol} \cdot \mathrm{L}^{-1}$, a $35 \%$ yield reduction was found. Similar results are reported by other authors (Dapoigny et al., 2000; Van Der Boon et al., 1990).

Evidently, the use of low-nitrate nutrient solution in the production of low-nitrate lettuce is limited due to a danger of a yield loss. However, our experiment showed that nitrate deprivation, similar to the one described (Dapoigny et al., 2000; Maršić and Osvald, 2002a, 2002b; Van der Boon et al., 1990; treatment B in our experiment), or even more restrictive deprivation (treatment C), does not result in a loss of a yield, when supply is lightdependent. This is in accordance with Henriques and Marcelis (2000) who reported on irradiance-dependent lettuce yield loss under $\mathrm{N}$ deprivation.

At the same time an efficient reduction in leaf nitrate was achieved in our study. Taking into account the growth parameters measured and a decrease in $\mathrm{NO}_{3}$ - we can conclude that the optimal results can be expected by the use of nutritional regime with slight to medium reduction of nitrate ( $\mathrm{B}$ to $\mathrm{C}$ in our experiment).

The analyses of total leaf $\mathrm{N}$ and nitrate (Fig. 2) show that nitrate is the part of the plant $\mathrm{N}$ pool responding to lower availability of nitrate $(\mathrm{N})$ in the hydroponic solution. Decreased nitrate concentration in the vacuole represents a reduction in osmotically active compounds and this reduction can result in lower water uptake by the cells and an increased dry matter content (Cárdenas-Navarro et al., 1999). A higher root dry matter content can be observed in both experiments in response to nitrate deprivation but no similar effect was observed in the leaves. Since there was a significant difference in accumulation of nitrate in outer and inner leaves (Fig. 2), it would be interesting to see whether the dry matter of outer leaves responded to different $\mathrm{N}$ treatments. Both experiments also showed that dry matter partitioning was influenced. While there was no change in the shoot to root ratio (dry matter basis) under slight $\mathrm{N}$ deprivation a clear decrease was found for medium and strong nitrate reduction. This indicates a well-known shift in allocation under N deficiency (Ågren and Ingestadt, 1987), the background of which could be clarified by detailed growth measurements or by the studies of the root architecture.

Nitrogen could affect lettuce growth through effects on photosynthetic rate and leaf area. Several studies suggest that $\mathrm{N}$ favors canopy expansion improving light interception, while there is little direct effect on photosynthesis (Grindlay, 1997; Henriques and Marcelis, 2000). When N supply is severely limited, however, low leaf $\mathrm{N}$ influences photosynthetic activity, according to the known asymptotic relationship between photosynthetic rate and the leaf N content (Evans, 1989; Hirose and Werger, 1987). In 
our case, total leaf $\mathrm{N}$ was significantly reduced in outer leaves (by $\approx 30 \%$ ), but in inner leaves only a slight decrease was observed in the late spring experiment. Gas exchange measurements on medium lettuce leaves showed that $\mathrm{N}$ deprivation and lower leaf $\mathrm{N}$ did not result in changes of carboxylation efficiency and photosynthetic capacity. Studying interactive effects of $\mathrm{N}$ and irradiance in lettuce Henriques and Marcelis (2000) found a minor effect of $\mathrm{N}$ on radiation use efficiency (RUE). Only with the strongest $\mathrm{N}$ deprivation (70\% of the daily $\mathrm{N}$ demand) and at high irradiance was RUE affected, which indicates a decreased photosynthetic capacity in response to reduced organic leaf $\mathrm{N}$ (10\% decrease). In the study by Dapoigny et al. (2000), however, a clear decrease in RUE was observed when nitrate concentration supplied to the lettuce was reduced from 7 to $3 \mathrm{mmol} \cdot \mathrm{L}^{-1}$. The latter result indicates that nitrate reduction, similar to the reduction used in our study, could result in down-regulation of photosynthesis. On the basis of gas-exchange measurements, however, this presumption has to be rejected in our case. This can be supported also by chlorophyll analyses that revealed only a minor transient decrease that appeared solely under strong $\mathrm{N}$ limitation. In addition, fluorescence measurements showed no effect on photochemical efficiency (Demšar and Vodnik, unpublished). All these results suggest that by limiting $\mathrm{N}$ supply, $\mathrm{N}$ is efficiently used for maintaining photosynthesis.

\section{Literature Cited}

Ågren, G.I. and T. Ingestadt. 1987. Root/shoot ratio: A balance between nitrogen productivity and photosynthesis. Plant Cell Environ. 10:579-586.

Alt, D. and A.M. Full. 1988. Control of the nitrogen status of lettuce by nitrate analysis of plant sap. Acta Hort. 222:23-27.

Andersen, L. and N.E. Nilesen. 1992. A new cultivation method for the production of the vegetables with low content of nitrate. Scientia Hort. 49:167-171.

Appenroth, K.J., R. Meco, V. Jourdan, and K. Lillo. 2000. Phytochrome and post-translational regulation of nitrate reductase in higher plants. Plant Sci. 159:51-56.

Behr, U. and H.J. Wiebe. 1992. Relation between photosynthesis and nitrate content of lettuce cultivars. Scientia Hort. 49:175-179

Blom-Zandstra, M. and A.H. Eenink. 1986. Nitrate concentration and reduction in different genotypes of lettuce. J. Amer. Soc. Hort. Sci. 111:908-911.

Blom-Zandstra, M., J.E.M. Lampe, and H.M. Ammerlaan. 1988. C and $\mathrm{N}$ utilization of two lettuce genotypes during growth under non-varying light conditions and after changing the light intensity. Physiol. Plant. 74:147-152.

Blom-Zandstra, M. and J.E.M. Lampe. 1985. The role of nitrate in the osmoregulation of lettuce (Lactuca sativa L.) grown at different light intensities. J. Expt. Bot. 36:1043-1052.

Cantliffe, D.J. 1972. Nitrate accumulation in spinach grown under different light intensities. J. Amer. Soc. Hort. Sci. 97:152-154.

Cárdenas-Navarro, R., S. Adamowicz, and P. Robin. 1999. Nitrate accumulation in plants: a role for water. J. Expt. Bot. 50: 613-624.

Dapoigny, L., S. de Tourdonnet, J. Roger-Estrade, M.H. Jeuffroy, and A. Fleury. 2000. Effect of nitrogen nutrition on growth and nitrate accumulation in lettuce (Lactuca sativa L.), under various conditions of radiation and temperature. Agronomie 20:843-855.

Escobar-Gutierrez, A.J., I.G. Burns, A. Lee, and R.N. Edmondson. 2002. Screening lettuce cultivars for low nitrate content during summer and winter production. J. Hort. Sci. Biotechnol. 77:232-237.

Evans, J.R. 1989. Photosynthesis and nitrogen relationships in leaves of $\mathrm{C}_{3}$ plants. Oecologia 78:9-19.

Gaudreau, L., J. Charbonneau, L.P. Vezina, and A. Gosselin. 1995. Effects of protoperiod and photosynthetic photon flux on nitrate content and nitrate reductase activity in greenhouse grown lettuce. J. Plant Nutr. 18:437-453.
Grindlay, D.J.C. 1997. Towards an explanation of crop nitrogen demand based on optimisation of leaf nitrogen per unit leaf area. J. Agr. Sci. 128:377-396.

Günes, A., W.H.K. Post, E.A. Kirkby, and M. Aktas. 1994. Influence of partial replacement of nitrate by amino acid nitrogen or urea in the nutrient medium on nitrate accumulation in NFT grown winter lettuce. J. Plant. Nutr. 17:1929-1939.

Henriques, A.R.D. and L.F.M. Marcelis. 2000. Regulation of growth at steady-state nitrogen nutrition in lettuce (Lactuca sativa $\mathrm{L}$.): Interactive effects of nitrogen and irradiance. Ann. Bot. 86:1073-1080.

Hirose, T. and M.J.A. Werger. 1987. Nitrogen use efficiency in instantaneous and daily photosynthesis of leaves in the canopy of a Solidago altissima stand. Physiol. Plant. 70:215-222.

Ioslovich, I. and I. Seginer. 2002. Acceptable nitrate concentration of greenhouse lettuce: Two optimal control policies. Biosystems Eng. 83:199-215.

Kowalska, I. 1997. Effect of urea, ammonium, and nitrate nitrogen on the yield and quality of greenhouse lettuce grown on different media. Folia Hort. 9:31-40.

Malorgio, F., A. Pardossi, D. Casarotti, and F. Tognoni. 1995. Contenuto di nitrati in Lattuga allevata in NFT. Colt. Protette 24:67-70.

Marschner, H. 1995. Mineral nutrition of higher plants. 2nd Ed. Academic, London.

Maršić, N.K. and J. Osvald. 2002a. The influence of different concentration of nitrogen in nutrient solution on plant growth and nitrate accumulation in aeroponically grown lettuce (Lactuca sativa L.). Agrochimica XLVI:56-65.

Maršić, N.K. and J. Osvald. 2002b. Effects of different nitrogen levels on lettuce growth and nitrate accumulation in iceberg lettuce (Lactuca sativa var. Capitata L.) grown hydroponically under greenhouse conditions. Gartenbauwissenschaf 67:128-134.

Official Journal. 1998. Commission regulation (EC) No. 1525/98, L 201, 17 July 1998. <http://europa.eu.int/eur-lex/en/oj/index-list.html>

Resh, H.M. 1995. Hydroponic food production. 5th ed. Woodbridge Press Pub. Co., Santa Barbara, Calif.

Roh, M.Y. and Y.B. Lee. 1996. Predictive control of concentration of nutrient solution according to integrated solar radiation during one hour in the morning. Acta Hort. 440:256-261.

Santamaria, P., A. Elia, and M. Gonnella. 1997a. Changes in nitrate accumulation and growth of endivie plants during light period as affected by nitrogen level and form. J. Plant Nutr. 20:1255-1266.

Santamaria, P., A. Elia, M. Gonnella, and F. Serio. 1997b. Effect of two $\mathrm{N}$ levels and two $\mathrm{NH}_{4}+: \mathrm{NO}_{3}-$ ratios on endive (Cichorium endivia L. cv. crispum Hegi). I. Growth, yield and water use. Adv. Hort. Sci. $11: 41-46$.

Scaife, A., M.E. Saraiva Ferreira, and M.K. Turner. 1986. Effect of nitrogen form on the growth and nitrate concentration of lettuce. Plant and Soil 94:3-16.

Schonbeck, M.W., R. Rivera, J. O’Brein, S. Ebinger, and R.E. Degregorio. 1991. Variety selection and cultural methods for lowering nitrate levels in winter greenhouse lettuce and endivie. J. Sustainable Agr. 2:49-75.

Steingröver, E., P. Ratering, and J. Siesling. 1986. Daily changes in uptake, reduction and storage of nitrate in spinach grown at low light intensity. Physiol. Plant. 66:550-556.

Tischner, R. 2000. Nitrate uptake and reduction in higher and lower plants. Plant Cell Environ. 23:1005-1024.

Urrestarazu, M., A. Postigo, M. Salas, A. Sanchez, and G. Carrasco. 1998. Nitrate accumulation reduction using chloride in the nutrient solution on lettuce growing by NFT in semiarid climate conditions. J. Plant Nutr. 21:1705-1714.

Van Der Boon, J., J.W. Steenhuizen, and E.G. Steingröver. 1990. Growth and nitrate concentration of lettuce as affected by total nitrogen and chloride concentration, $\mathrm{NH}_{4} / \mathrm{NO}_{3}$ ratio and temperature of the recirculating nutrient solution. J. Hort. Sci. 65:309-321.

Vodnik, D., P. Hardy, I. Maček, D. Kastelec, S. Lojen, and F. Batič. 2002. Photosynthesis of cockspur [Echinochloa crus-galli (L.) Beauv.] at sites of naturally elevated $\mathrm{CO}_{2}$ concentration. Photosynthetica 40:575-579. 